\title{
Territorial features of the development of higher education in Russia
}

\section{Características territoriais do desenvolvimento do ensino superior na Rússia}

\section{Características territoriales del desarrollo de la educación superior en Rusia}

\author{
Iuliia S. Pinkovetskaia1 ${ }^{1 D}$ \\ ${ }^{1}$ Ulyanovsk State University, Ulyanovsk, Russia. \\ Corresponding author: \\ Iuliia S. Pinkovetskaia \\ Email: pinkovetskaia@gmail.com \\ How to cite: Pinkovetskaia, I. S. (2021). Territorial features of the development of higher education in Russia. Revista \\ Tempos e Espaços em Educação, 14(33), e16214. http://dx.doi.org/10.20952/revtee.v14i33.16214
}

\begin{abstract}
The purpose of our study was to evaluate the indicators characterizing the presence of higher education organizations in the regions of Russia, as well as the proportion of students in the total population of each of the regions. The study used as initial information official statistical data on the development of higher education in 82 regions of Russia in 2020, as well as information on the population in each of the regions. We have developed econometric models that describe the distribution of access to higher education in the regions. The study allowed us to estimate the number of higher education organizations per one million residents and the share of students in the population of the regions. The regions with the maximum and minimum values of the considered indicators were identified. It is shown that higher education has received significant development in Russia.
\end{abstract}

Keywords: Higher education. Number of students. Number of universities. Regions of Russia.

\section{RESUMO}

O objetivo do nosso estudo foi avaliar indicadores que caracterizam a presença de organizações de ensino superior nas regiões da Rússia, bem como a proporção de estudantes na população total de cada uma das regiões. O estudo utilizou estatísticas oficiais sobre o desenvolvimento do ensino superior em 82 regiões da Rússia em 2020, bem como informações sobre o tamanho da população em cada uma das regiões, como informação inicial. Desenvolvemos modelos econométricos descrevendo a distribuição do acesso ao ensino superior nas regiões. O estudo estimou o número de organizações de ensino superior por milhão de habitantes e a proporção de estudantes na 
população das regiões. Regiões com valores máximo e mínimo dos indicadores considerados foram identificadas. É mostrado que o ensino superior recebeu um desenvolvimento significativo na Rússia.

Palavras-chave: Ensino superior. Número de estudantes. Número de universidades. Regiões da Rússia.

\section{RESUMEN}

El objetivo de nuestro estudio fue evaluar los indicadores que caracterizan la presencia de organizaciones de educación superior en las regiones de Rusia, así como la proporción de estudiantes en la población total de cada una de las regiones. El estudio utilizó estadísticas oficiales sobre el desarrollo de la educación superior en 82 regiones de Rusia en 2020, así como información sobre el Tamaño de la población en cada una de las regiones, como información de referencia. Hemos desarrollado modelos econométricos que describen la distribución del acceso a la educación superior en las regiones. El estudio permitió estimar el número de organizaciones de educación superior por millón de habitantes y la proporción de estudiantes en la población de las regiones. Se identificaron las regiones con valores máximos y mínimos de los indicadores considerados. Se muestra que la educación superior ha recibido un desarrollo significativo en Rusia.

Palabras clave: Educación superior. Número de estudiantes. Número de universidades. Regiones de Rusia.

\section{INTRODUCTION}

Universities and other institutions providing higher education have a decisive positive impact on the socio-economic development of modern countries (Jaspers, 1960). Based on the concept of human capital, the potential of people with higher education allows us to solve a wide range of tasks facing developed and developing countries, as well as to increase the efficiency of national economies. In the twenty-first century, there is such a phenomenon as mass access of people to higher education (Guri-Rosenblit et al., 2007). The total number of students in all countries in 2016 amounted to 218 million people, that is, it increased by 1.5 times compared to 2006 (La mobilité internationale, 2019).

Given the above, for most developed and developing economies, an urgent problem is the assessment of indicators characterizing the availability of higher education (Stiglitz, 2014; Douglass, 2011). Our research was devoted to this issue. Studying the current level of solving this problem is important both for state bodies regulating activities in this area, and directly for potential students. At the same time, the study of the contribution of higher education to regional development is relevant. The presence of regional universities increases the attractiveness of regions, positively affects their economic growth and, most importantly, ensures the retention of school graduates in the regional labor market (Abel, Deitz, 2011; Ciriaci, 2014).

Despite the existence of extensive research on the problem of the development of higher education, up to now not enough attention has been paid to the regional peculiarities of solving this problem. Thus, the article responds to calls to assess the differentiation of the level of higher education in the regions, expressed, in particular, in the works (Cervantes, 2017; Unger, Polt, 2017).

To date, the sphere of higher education in Russia has received significant development. Thus, in 2020, 1,259 organizations specialized in higher educational activities. The total number of students enrolled in them was 4049333 people. Of these, 2429308 students were full-time students, 206139 were evening students, 1413886 were part-time students (Official statistical information on additional professional and higher education, 2021).

The purpose of our study was to evaluate the indicators characterizing the presence of higher education organizations in the regions of Russia, as well as the proportion of students in the total population of each of the regions. Our article is aimed at obtaining a certain empirical and 
methodological contribution to the knowledge about the possibility of obtaining higher education in the regions of Russia. This contribution consists in the fact that the author's methodology for modeling the assessment of the level of development of higher education in the regions of Russia using the density functions of the normal distribution is proposed. The empirical contribution is associated with the determination of the average values and standard deviations by region of such indicators as the number of higher education organizations per one million residents of the region, the proportion of students receiving higher education in the population of the region, the proportion of students admitted to higher education organizations in the population of the region, the proportion of students who received higher education in the population of the region. In addition, the regions with the maximum and minimum values of these indicators are determined.

The structure of this work is as follows. Section 2 presents an overview of scientific publications in recent years describing the level of higher education in Russia. Section 3 describes the methodology, source data and design used when writing the article. The simulation results are presented in section 4 of the article. Section 5 discusses the results. The last sections contain conclusions and bibliographic references.

\section{LITERATURE REVIEW}

A number of scientific publications published in 2018-2021 were devoted to the problem of assessing such an aspect of the development of higher education in Russia as the saturation of the country and its regions with higher education organizations, as well as people's access to training under appropriate programs. A brief description of these publications is given in table 1.

Table 1. Scientific publications on the volume of higher education development in Russia.

\begin{tabular}{|c|c|c|c|}
\hline Authors & Problems under study & Objects of study & Type of indicators \\
\hline 1 & 2 & 3 & 4 \\
\hline Volchik et al. (2019) & $\begin{array}{l}\text { Analysis of the number of } \\
\text { universities and their organizational } \\
\text { and legal forms in 1980-2017. }\end{array}$ & $\begin{array}{l}\text { Russia and Rostov } \\
\text { region }\end{array}$ & Absolute \\
\hline Cherednichenko (2018) & $\begin{array}{l}\text { Distribution of the number of } \\
\text { students who entered universities in } \\
2000-2017 \text { by forms of study }\end{array}$ & Russia & Absolute \\
\hline Prosalova et al. (2019) & $\begin{array}{l}\text { The study of the dynamics of } \\
\text { changes in the number of students } \\
\text { who received higher education in } \\
\text { 2013-2017. }\end{array}$ & Russia & Relative \\
\hline Bezhanova et al. (2019) & $\begin{array}{l}\text { Forecasting the number of students } \\
\text { in higher educational institutions. } \\
\text { Assessment of the demand for }\end{array}$ & Russia & Absolute \\
\hline Dorofeeva (2020) & $\begin{array}{l}\text { higher education services for the } \\
\text { period from } 2007 \text { to } 2019 \text {. }\end{array}$ & Russia & Absolute \\
\hline Belyaev (2021) & $\begin{array}{l}\text { Analysis of the dynamics of changes } \\
\text { in the total number of students in } \\
\text { comparison for } 2015 \text { and } 2019 .\end{array}$ & $\begin{array}{l}\text { Russia and federal } \\
\text { districts }\end{array}$ & Absolute \\
\hline Kurbatova et al. (2021) & $\begin{array}{l}\text { Higher education in the conditions of } \\
\text { regions where mining is } \\
\text { concentrated. }\end{array}$ & 27 Russian regions & Relative \\
\hline Ivanova et al. (2021) & $\begin{array}{l}\text { The state and prospects of the } \\
\text { university's development, including } \\
\text { the analysis of the number of } \\
\text { students. }\end{array}$ & Novgorod region & Absolute \\
\hline $\begin{array}{l}\text { Leontieva } \\
\text { (2021) }\end{array}$ & $\begin{array}{c}\text { Strategy for the development of } \\
\text { higher education in the regions of } \\
\text { Russia. }\end{array}$ & Russian regions & Absolute, relative \\
\hline
\end{tabular}




\begin{tabular}{ccc}
\hline & $\begin{array}{c}\text { Analysis of the number of students } \\
\text { studying in higher education } \\
\text { institutions in the region for the } \\
\text { period from } 2000 \text { to } 2019\end{array}$ & Kemerovo region \\
\hline
\end{tabular}

Source: The table is compiled by the author on the basis of the information provided in the RSCl.

Based on the information given in Table 1, it can be stated that the problem of research on the development of higher education is relevant in Russia. Most of the studies reviewed analyzed the number of students and the number of organizations in Russia as a whole, its individual federal districts and regions. At the same time, a comprehensive assessment of the distribution of the number of students and educational organizations in all regions of Russia has not been sufficiently reflected in scientific publications. It can be noted that a comparative analysis of relative indicators that take into account a significant difference in the number of residents by region was not carried out in most studies. Thus, absolute indicators were given in $70 \%$ of the studies indicated in the table. Taking this into account, it seems appropriate to conduct a comparative analysis of the existing specific indicators of the level of development of higher education in all regions of Russia.

\section{METHODOLOGY AND DESIGN}

The organizations of higher education considered in this article include those that functioned in 2020. At the same time, students who studied in these organizations under the bachelor's degree (four years of study), specialty (five years of study), as well as master's degree programs were taken into account.

The research process included five stages. At the first stage, the initial data describing the number of higher education organizations and the number of their students by region in 2020 were formed. In addition to the number of students receiving higher education in each of the regions, data on the number of people accepted for higher education programs, as well as those who received such education in 2020, were considered. At the second stage, indicators were calculated that characterize the number of organizations per one million residents and the specific weights of the number of students in the total number of residents in each of the regions. At the third stage, the distribution of indicators by region was evaluated based on the development of mathematical models. At the fourth stage, the average values of indicators for the regions of Russia were determined, as well as the ranges in which the values of these indicators are located for most of them.

The study used the official statistical information of the Ministry of Science and Higher Education of the Russian Federation for 2020 on the number of higher education organizations and the number of students in 82 regions of Russia (Official statistical information on additional professional and higher education, 2021). In addition, we used empirical data from the Federal State Statistics Service of Russia on the population for each of the regions in 2020 (Official statistical information on the population of the Russian Federation by municipalities, 2021).

In our study, three hypotheses were tested:

hypothesis 1 - organizations that provide the opportunity to obtain higher education are currently available in all regions of Russia;

hypothesis 2 - the values of the four indicators under consideration have a significant differentiation between different regions;

hypothesis 3 - regions which are characterized by maximum and minimum values each of four indicators, have various geographical location among federal districts.

The evaluation of the values of the four considered indicators was carried out on the basis of economic and mathematical modeling of the initial empirical data. As models, we used the density functions of the normal distribution, the method of developing which for estimating the 
values of specific indicators was proposed by the author. Some aspects of the use of the methodology are given in the works (for example, Pinkovetskaia, Slepova, 2018; Pinkovetskaia et al., 2021). During the development of the functions, the initial empirical data were grouped according to the ranges of changes in the values of the indicators. These data groups can be geometrically represented in the form of corresponding histograms. Data approximation using normal distribution functions was carried out using generally accepted statistical methods. It is important to note that the average values of the considered indicators, as well as their standard deviations for the density functions of the normal distribution, were displayed in the formulas of the developed functions themselves. Therefore, by constructing a specific function, we get the specified parameters of the considered indicators without additional calculations.

The obtained functions allowed us to determine the average values of each of the four indicators for the regions under consideration, as well as the ranges of their changes characteristic of most regions. In addition, the study identified regions in which the considered indicators have values above the upper and below the lower boundaries of the ranges. The boundaries of the indicator ranges for $68 \%$ of the regions were determined based on the average values of the indicators and the corresponding standard deviations. The lower bound of the interval is equal to the difference between the mean and the standard deviation, and the upper bound is equal to their sum.

\section{MODELING AND RESULTS}

In the course of the computational experiment, economic and mathematical modeling was carried out on the basis of empirical data. The models that describe the distributions $\left(y_{1}, y_{2}, y_{3}\right.$, $y_{4}$ ) of the three indicators $\left(x_{1}, \% ; x_{2}, \% ; x_{3} ; x_{4}\right)$ across all 82 Russian regions are shown below:

- the number of higher education organizations per one million residents of the region

$$
y_{1}\left(x_{1}\right)=\frac{300.67}{3.16 \times \sqrt{2 \pi}} \cdot e^{-\frac{\left(x_{1}-8.33\right)^{2}}{2 \times 3.16 \times 3.16}}
$$

- the proportion of students receiving higher education in the population of the region, $\%$

$$
y_{2}\left(x_{2}\right)=\frac{71.75}{0.98 \times \sqrt{2 \pi}} \cdot e^{-\frac{\left(x_{2}-2.35\right)^{2}}{2 \times 0.98 \times 0.98}}
$$

- the proportion of students admitted to higher education organizations in the population of the region, $\%$

$$
y_{3}\left(x_{3}\right)=\frac{30.07}{0.29 \times \sqrt{2 \pi}} \cdot e^{-\frac{\left(x_{3}-0.61\right)^{2}}{2 \times 0.29 \times 0.29}} .
$$

- the proportion of students who received higher education in the population of the region, $\%$

$$
y_{4}\left(x_{4}\right)=\frac{21.87}{0.21 \times \sqrt{2 \pi}} \cdot e^{-\frac{\left(x_{4}-0.48\right)^{2}}{2 \times 0.21 \times 0.21}}
$$

The quality of functions (1)-(4) we tested using such criteria: by the Kolmogorov-Smirnov, the Pearson and the Shapiro-Wilk. Calculated values of criteria are given in table 2. 
Table 2. Calculated values of criteria.

\begin{tabular}{|c|c|c|c|}
\hline \multirow[b]{2}{*}{ Indicators } & \multicolumn{3}{|c|}{ Criteria } \\
\hline & $\begin{array}{l}\text { The Kolmogorov- } \\
\text { Smirnov test }\end{array}$ & $\begin{array}{l}\text { The Pearson } \\
\text { test }\end{array}$ & $\begin{array}{l}\text { The Shapiro-Wilk } \\
\text { test }\end{array}$ \\
\hline $\begin{array}{l}\text { the number of higher education organizations per one } \\
\text { million residents of the region }\end{array}$ & 0.05 & 1.72 & 0.98 \\
\hline $\begin{array}{l}\text { the proportion of students receiving higher education in the } \\
\text { population of the region }\end{array}$ & 0.07 & 4.84 & 0.96 \\
\hline $\begin{array}{l}\text { the proportion of students admitted to higher education } \\
\text { organizations in the population of the region }\end{array}$ & 0.06 & 4.82 & 0.96 \\
\hline $\begin{array}{l}\text { the proportion of students who received higher education } \\
\text { in the population of the region }\end{array}$ & 0.05 & 5.12 & 0.95 \\
\hline
\end{tabular}

Source: The data in the table are based on the results of calculated functions.

Information given in column 2 of Table 2 showed that all calculated values are less than the critical value by the Kolmogorov-Smirnov test $(0.174)$ at significant level equal 0.05 . Data in column 3 are less than critical value of Pearson criterion (9.49). Data in column 4 exceed critical value 0.93 Shapiro-Wilk test with significant level of 0.01 . Thus, the computational experiment showed that all nine developed functions have high quality.

At the next stage of the study, the values of indicators characterizing the level of development of higher education in the regions of Russia were determined. The values of the indicators, the average by region, are shown in column 2 of Table 3 . The average values were determined by the basic functions (1)-(4). The third column indicates the standard deviation for discussing indicators. The values of the indicators characterizing the upper and lower boundaries of the intervals corresponding to the majority of regions are shown in column 4 . We calculate the lower limits as the difference between the average value and the standard deviation, and we calculate the upper limits as the sum of the average value and the standard deviation.

Table 3. The values of indicators describing the level of development of higher education in the regions of Russia in 2020.

\begin{tabular}{|c|c|c|c|}
\hline Indicator numbers & Average values & Standard deviation & Values for most regions \\
\hline 1 & 2 & 3 & 4 \\
\hline $\begin{array}{c}\text { the number of higher education } \\
\text { organizations per one million residents of } \\
\text { the region }\end{array}$ & 8.33 & 3.16 & $5.17-11.49$ \\
\hline $\begin{array}{l}\text { the proportion of students receiving higher } \\
\text { education in the population of the region, } \% \\
\text { the proportion of students admitted to }\end{array}$ & 2.35 & 0.98 & $1.37-3.33$ \\
\hline $\begin{array}{l}\text { higher education organizations in the } \\
\text { population of the region, } \% \\
\text { the proportion of students who received }\end{array}$ & 0.61 & 0.29 & $0.32-0.90$ \\
\hline $\begin{array}{l}\text { higher education in the population of the } \\
\text { region, } \%\end{array}$ & 0.48 & 0.21 & $0.27-0.69$ \\
\hline
\end{tabular}

Source: The calculations are carried out by the author on the basis of functions (1)-(4).

\section{DISCUSSION}

Analysis of empirical data in 2020 showed that residents of all regions of Russia, without exception, can receive higher education in region where he live, since there are corresponding organizations in each of the regions. Thus, the first hypothesis was confirmed.

The data in Table 3 show that, on average, on 82 regions of Russia, the number of higher education institutions is slightly more than 8 per one million residents of the regions. In most regions, this indicator is in the range from 5.2 to 11.5 higher education organizations for every million residents. 
The average value of the proportion of students receiving higher education in the Russian regions is almost $2.4 \%$ of the total population of the regions. That is, approximately every fortieth resident is a student studying under the higher education program. The values of indicators for most regions range from $1.4 \%$ to $3.3 \%$.

The average value for the Russian regions of the proportion of students who started studying under higher education programs in 2020 was about $0.6 \%$ of the number of residents of the regions. The values of this indicator, typical for most regions, were in the range from $0.3 \%$ to $0.9 \%$.

The average value of the proportion of students who received higher education in the Russian regions in 2020 was not much less than $0.5 \%$. It can be noted that the number of graduates was less than those who began to receive higher education. This is logical, since not all students fully master higher education programs and receive diplomas. The values of the proportion of students who received higher education, typical for most regions, were in the range from $0.3 \%$ to $0.7 \%$.

To test hypothesis 2 on the differentiation of indicators by regions, an analysis of the extent of variation of each of the indicators presented in table 3 was carried out. For this we used standard deviations that are in column 3. Variation indices are as follows: for the first indicator - $38 \%$, for the second indicator $-42 \%$, for the third indicator $-48 \%$, for the forth indicator $-44 \%$. This analysis showed a significant differentiation of the values of each of the three indicators in the countries under consideration, that is, the hypothesis 2 was confirmed.

The next step was to identify the Russian regions where the maximum and minimum values of each indicator were noted. In this case, the maximum values are those that exceed the upper limits of the ranges specified in column 4 of Table 3 , and the minimum values are those that are less than the lower limits of the specified ranges. The results of this analysis are shown in table 4. Along with the lists of regions, this table also provides values of indicators on regions and geographical location of regions.

Table 4. Characteristics of Russian regions with maximum and minimum indicator values.

\begin{tabular}{|c|c|c|c|}
\hline Indicators & Region & Value & Federal district \\
\hline 1 & 2 & 3 & 4 \\
\hline \multicolumn{4}{|c|}{ With maximum values of indicators } \\
\hline \multirow{20}{*}{$\begin{array}{l}\text { the number of higher } \\
\text { education organizations per } \\
\text { one million residents of the } \\
\text { region }\end{array}$} & Moscow city & 11.83 & Central \\
\hline & Yaroslavl region & 11.97 & Central \\
\hline & Orel region & 12.27 & Central \\
\hline & Saint Petersburg city & 12.60 & North-West \\
\hline & Pskov region & 12.78 & North-West \\
\hline & Astrakhan region & 12.93 & South \\
\hline & Sevastopol city & 13.36 & South \\
\hline & Sakha republic & 15.43 & Far Eastern \\
\hline & Kamchatka territory & 15.97 & Far Eastern \\
\hline & Smolensk region & 17.11 & Central \\
\hline & Chukotka autonomous district & 19.89 & Far Eastern \\
\hline & \multicolumn{3}{|c|}{ With minimum values of indicators } \\
\hline & Chechen republic & 2.71 & North Caucasian \\
\hline & Tyumen region & 2.93 & Ural \\
\hline & Kostroma region & 3.16 & Central \\
\hline & Novgorod region & 3.35 & North-West \\
\hline & Kabardino-Balkar republic & 3.45 & North Caucasian \\
\hline & Ingushetia republic & 3.94 & North Caucasian \\
\hline & Sakhalin region & 4.10 & Far Eastern \\
\hline & Mari El republic & 4.42 & Privolzhsky \\
\hline
\end{tabular}




\begin{tabular}{|c|c|c|c|}
\hline & Altai republic & 4.54 & Siberian \\
\hline \multirow{19}{*}{$\begin{array}{l}\text { the proportion of students } \\
\text { receiving higher education in } \\
\text { the population of the region }\end{array}$} & \multicolumn{3}{|c|}{ With maximum values of indicators } \\
\hline & Kursk region & $3.35 \%$ & Central \\
\hline & Novosibirsk region & $3.49 \%$ & Siberian \\
\hline & Tatarstan republic & $3.64 \%$ & Privolzhsky \\
\hline & Voronezh region & $3.66 \%$ & Central \\
\hline & Oryol region & $3.74 \%$ & Central \\
\hline & Omsk region & $3.81 \%$ & Siberian \\
\hline & Tomsk region & $5.35 \%$ & Siberian \\
\hline & Moscow city & $5.70 \%$ & Central \\
\hline & Saint Petersburg city & $5.75 \%$ & North-West \\
\hline & \multicolumn{3}{|c|}{ With minimum values of indicators } \\
\hline & Chukotka autonomous district & $0.28 \%$ & Far Eastern \\
\hline & Leningrad region & $0.34 \%$ & North-West \\
\hline & Murmansk region & $0.89 \%$ & North-West \\
\hline & Moscow region & $1.02 \%$ & Central \\
\hline & Sakhalin region & $1.13 \%$ & Far Eastern \\
\hline & Altai republic & $1.20 \%$ & Siberian \\
\hline & Jewish autonomous region & $1.23 \%$ & Far Eastern \\
\hline & Tyumen region & $1.34 \%$ & Ural \\
\hline \multirow{16}{*}{$\begin{array}{l}\text { the proportion of students } \\
\text { admitted to higher education } \\
\text { organizations in the } \\
\text { population of the region }\end{array}$} & \multicolumn{3}{|c|}{ With maximum values of indicators } \\
\hline & Orel region & $0.91 \%$ & Central \\
\hline & Voronezh region & $0.97 \%$ & Central \\
\hline & Novosibirsk region & $0.98 \%$ & Siberian \\
\hline & Tatarstan republic & $0.98 \%$ & Privolzhsky \\
\hline & Omsk region & $1.13 \%$ & Siberian \\
\hline & Tomsk region & $1.54 \%$ & Siberian \\
\hline & Saint Petersburg city & $1.72 \%$ & North-West \\
\hline & Moscow city & $1.73 \%$ & Central \\
\hline & \multicolumn{3}{|c|}{ With minimum values of indicators } \\
\hline & Chukotka autonomous district & $0.05 \%$ & Far Eastern \\
\hline & Leningrad region & $0.06 \%$ & North-West \\
\hline & Murmansk region & $0.22 \%$ & North-West \\
\hline & Jewish autonomous region & $0.24 \%$ & Far Eastern \\
\hline & Sakhalin region & $0.25 \%$ & Far Eastern \\
\hline & Moscow region & $0.26 \%$ & Central \\
\hline \multirow{12}{*}{$\begin{array}{l}\text { the proportion of students } \\
\text { who received higher } \\
\text { education in the population } \\
\text { of the region }\end{array}$} & \multicolumn{3}{|c|}{ With maximum values of indicators } \\
\hline & Kursk region & $0.70 \%$ & Central \\
\hline & Mordovia republic & $0.71 \%$ & Privolzhsky \\
\hline & Khabarovsk territory & $0.71 \%$ & Far Eastern \\
\hline & Omsk region & $0.76 \%$ & Siberian \\
\hline & Tatarstan republic & $0.79 \%$ & Privolzhsky \\
\hline & Voronezh region & $0.79 \%$ & Central \\
\hline & Adygea republic & $0.80 \%$ & North Caucasian \\
\hline & Oryol region & $0.82 \%$ & Central \\
\hline & Tomsk region & $0.99 \%$ & Siberian \\
\hline & Saint Petersburg city & $1.18 \%$ & North-West \\
\hline & Moscow city & $1.30 \%$ & Central \\
\hline
\end{tabular}

Source: Developed by the author on the basis of data from table 3.

Table 4 provides information on the geographical location of regions (column 3), i.e. to which of federal districts in Russia they devote (column 4). The analysis of this information showed that there is no relationship between the maximum and minimum values of indicators and the territorial 
location of regions. That is, regions with high and low values of indicators are located in different federal districts. Thus, we can state the confirmation of hypothesis 3.

\section{CONCLUSION}

In general, it should be noted that our research makes a number of important contributions to the knowledge of the territorial features of the development of higher education in Russia. While most scientific publications are devoted to general problems of higher education, our work is devoted to the analysis of territorial aspects of the development of this phenomenon. In addition, the article proposed a methodology for modeling the distribution of indicator values by region. The purpose of our study was to evaluate the indicators characterizing the presence of higher education organizations in the regions of Russia, as well as the proportion of students in the total population of each of the regions. The conclusions that have scientific novelty and originality are given below. First, it was found that higher education organizations in 2020 were in each of the regions, that is, their residents could study according to the relevant programs without leaving their region. In the course of the study, a method was proposed for evaluating indicators characterizing the number of higher education organizations, as well as the share of students in the population by region, using the density functions of the normal distribution. On the basis of the proposed methodology, the distribution of the corresponding indicators for all 82 regions of Russia was estimated. The results of the computational experiment showed that, on average, there were a little more than eight higher education organizations per one million residents in the regions. It is proved that every fortieth resident in 2020 studied under higher education programs. It is shown that about $0.6 \%$ of the population started studying in higher education organizations in the year under review, and about $0.5 \%$ of the population received university diplomas. The analysis showed the presence of a significant differentiation of the values of the considered indicators by region.

The regions that were characterized by the maximum and minimum values of the four considered indicators were identified. The study showed that the geographical location of the regions does not significantly affect the maximum and minimum values of the indicators.

The practical significance of the study for the government is to take into account the existing territorial differences in the development of higher education in the regions of Russia. The results of the work can be used in the activities of federal and regional structures related to the support of educational processes, when justifying their planned activities, increasing the level of accessibility of higher education. For potential students, data on the distribution of higher education organizations by region and the proportion of students in the population of the regions may be of particular interest.

The new knowledge gained is of interest and can be used in the educational process at universities. The study was not limited to empirical data, as it was based on official statistical information for all 82 regions of Russia. Further research may be aimed at establishing the gender characteristics of higher education in Russia.

Authors' Contributions: Pinkovetskaia, I. S.: conception and design, acquisition of data, analysis and interpretation of data, drafting the article, critical review of important intellectual content. The author has read and approved the final version of the manuscript.

Ethics Approval: Not applicable.

Acknowledgments: Not applicable.

\section{REFERENCES}

Abel, J. R.., \& Deitz, R. (2011). Do colleges and universities increase their region's human capital? Journal of Economic Geography, 12(3), 667-691. 
Belyaev, S. (2021). Dedaluation of the prestige of higher education as a factor in reducing the number of students studying by correspondence. Baltic Humanitarian Journal, 10(34), 21-24.

Bezhanova, E., Shkhagoshev, R., \& Shetov, A. (2019). Analysis and assessment of the influence of various factors on the dynamics of the number of Russian university students. State and municipal administration. Scientific notes, $4,90-$ 95.

Bobko, T. V., Prituzhalova, Y. A., \& Petrova, T. V. (2021). Assessment of the impact of economic indicators of regional development on the number of students at educational levels of training in the Kemerovo region. Artificial societies, 16(1), 1-12.

Cervantes, M. (2017). Higher education institutions in the knowledge triangle. Foresight and STI Governance, 11(2), 27-42.

Cherednichenko, G. A. (2018). Students of the higher school of the Russian Federation 2000-2017 (statistical characteristics). Education and science in Russia: the state and potential of development, 3, 217-241.

Ciriaci, D. (2014). Does university quality influence the interregional mobility of students and graduates? The case of Italy. Regional Studies, 48(10), 1592-1608.

Dorofeeva, T. P. (2020). The relationship of economic and demographic factors and the demand for higher education services. Bulletin of the Kemerovo State University. Political, Sociological and Economic Sciences, 5(4), 534-542.

Douglass, J. (2011). Higher education's new global order: How and why governments are creating structured opportunity markets. Educational Studies Moscow, 1, 73-98.

Guri-Rosenblit, S., Sebkova, H., \& Teichler, U. (2007). Massification and diversity of higher education systems: interplay of complex dimensions. Higher Education Policy, 20(4), 373-389.

Ivanova, O., Daneikin, Y., Trifonov, V., Patturi, Y., \& Chopozov, S. (2021). Implementation of the "third mission" of the university: determining the multiplicative effect of increasing the student body for regional development. Innovations and investments, 5, 68-74.

Jaspers, K. (1960). The Idea of the University. Boston. Beacon Press.

Kurbatova, M. V., Donova, I. V., Kranzeeva, E. A. (2021). Higher education in resource-type regions: between the tasks of departmental and regional development. Terra Economicus, 19(1), 109-123.

La mobilité internationale des étudiants: S'organiser pour les défis à venir. (2019). Paris. La Documentation Française. Available at: https://www.vie-publique.fr/sites/default/files/rapport/pdf/194000726.pdf

Leontieva, L. S., Avilkina, S. V. (2021). The system of higher education as a strategic resource of regional development. Public administration. Electronic bulletin, 86, 200-219.

Official statistical information on additional professional and higher education. (2021). Ministry of Science and Higher Education of the Russian Federation. Available at: https://minobrnauki.gov.ru/action/stat/highed/

Official statistical information on the population of the Russian Federation by municipalities. (2021). Federal State Statistics Service. Available at: https://rosstat.gov.ru/compendium/document/13282?print=1

Pinkovetskaia, I., \& Slepova, V. (2018). Estimation of Fixed Capital Investment in SMEs: the Existing Differentiation in the Russian Federation. Business Systems Research, 9(1), 65-78.

Pinkovetskaia, I., Nuretdinova, Y., Nuretdinov, I., \& Lipatova, N. (2021). Mathematical modeling on the base of functions density of normal distribution. Revista de la Universidad Del Zulia, 12(33), 34-49.

Prosalova, V. S., Loksha, A.V., \& Vovna, A.V. (2019). Relevance of development and application of methods of forecasting of number of students of higher education institutions. Azimuth of Scientific Research: Pedagogy and Psychology, 8(27), 194-196.

Stiglitz, J. E. Creating a Learning Society: A New Approach to Growth, Development, and Social Progress (Kenneth Arrow Lecture Series). Columbia: Columbia University Press. 680 p., 2014.

Unger, M., \& Polt, W. (2017). The knowledge triangle between research, education and innovation - A conceptual discussion. Foresight-Russia, 2, 10-26.

Volchik, V., Zhuk, A., Oganesyan, A., \& Abrhám, J. (2019). Analysis of the institutional building and sustainable development of higher education in transition economies. Entrepreneurship and Sustainability Issues, 7(2), 14131423. 
Received: 2 July 2021 | Accepted: 6 August 2021 | Published: 14 August 2021

(c) (1)

This is an Open Access article distributed under the terms of the Creative Commons Attribution License, which permits unrestricted use, distribution, and reproduction in any medium, provided the original work is properly cited. 